\title{
Molecular detection of MSRA Erythromycin-Resistant gene in Staphylococcus spp
}

\begin{abstract}
Osamah M. Hassan * MSc
Abstract:

Background: The resistance to antimicrobial factors is an increasingly global problem worldwide, especially among nosocomial bacteria. Staphylococci have become one of the common causes of nosocomialinfections. Multi drug-resistant staphylococci pose a growing problem for human health.

ObjectiveThis study was carried out to evaluate the association between the antibiotic susceptibility patterns and the msrA Erythromycin-Resistant gene in staphylococci isolates obtained from various clinical samples of patients.

JFac Med Baghdad

Methods: A total of 25 staphylococci clinical isolates were collected from the central Health Lab. DNA from 2017; Vol.59, No.1

Receive Nov. 2016

Accepted Jan 2017 each sample was extracted and The gene implicated in resistance to erythromycin (msrA) was amplified using PCR method.

Results:The PCR of msr A gene showed positive 16 out of 25 for isolated staphylococci (gave 163 sized amplicons), whichresults may be considered as an important criterion to treating Staphylococcal infections.

Conclusion: The PCR is a useful and practical device for the routine diagnosis of macrolide resistance staphylococci use to be microbiology laboratory work flow .the detection of resistance genes by PCR was more reliable, accurate and specific than other methods of detection.

Key words : PCR,msrA, staphylococci, erythromycin
\end{abstract}

\section{Introduction:}

The resistance to antimicrobial factors is an increasingly global problem worldwide, especially among nosocomial bacteria. Staphylococci have become one of the common causes of nosocomial infections. Multi drug-resistant staphylococci pose a growing problem for human health. 1,2.Macrolides are antibiotics widely used for thetreatment of human and animal infections. The use of these antibiotics has been accompanied by selection of resistant bacteria, e.g. Staphylococci(3). Resistant bacteria, orgenetic determinants of resistance, can be transmitted from animals to humans by food stuffs (4)The msrA gene encodes macrolide efflux pump which is mostly present in $\mathrm{S}$. aureus, belongs to the $\mathrm{ABC}$ transporter family, and stimulate resistance to 14-and 15-membered macrolides (M phenotype) and streptogramins B (5).The structural changes in ribosomal RNA (rRNA) whichprevent the connection of macrolides are the other important resistance mechanism conferring highlevel resistance.(6)The methylation of rRNA leads to crossresistance to macrolides, lincosamides and streptogramin $\mathrm{B}$ (MLSB-resistance), which can be either constitutive (cMLSB) or inducible (iMLSB) (7).It is very important clinically to find the difference between isolates with iMLSB resistance encoded by (erm genes) and isolates with efflux-mediated resistance due to the (msrA gene) (8). These genes, erm(A), erm(C) and $\operatorname{msr}(\mathrm{A})$ were found frequently in Staphylococcus, alone or in combination, more than other genes $(9,10)$. The resistant genes detected can be lead to find the best treatment of the infection . combination of molecular and blood culture analyzes would

*Dept. of Basic Medical Science, Dentistry College, University AlMustansiriyah University.

Osamagenetic@gmial.com significantly increase the rate for pathogen detection. This molecular method (pcr) which detects pathogens .rapidly complements conventionalTimely detection of the active pathogens(11).

\section{Materials and methods:}

Sample collection, a total of 25 clinical isolates of staphylococci were isolated from blood wounds, urine and pus samples .The samples were sent immediately to the microbiology laboratory at genetic engineer institute university of Baghdad. The samples were inoculated onto 5\% sheep blood agar plates and incubated at $37^{\circ} \mathrm{C}$ for $48 \mathrm{~h}$.the isolates were cultured on mannitol salt agar (MSA), which is considered a selective and differential growth medium that is used for encouraging the growth of staphylococci. The selection of staphylococci was on the basis of colony morphology, Gram staining, biochemical tests which are catalase test, DNASE test and coagulase tests. Several biochemical tests were carried out to identify the staphylococci.All Gram-positive isolates gave positive results in the Catalase tests. In order to support the previous biochemical test, DNase tests and tube coagulase tests were carried out. The combination of all the biochemical tests increased the sensitivity to identify the staphylococci among the bacterial isolates. (25) isolates showed a positive coagulase test. DNase results were positive in $20(83.33 \%)$ and the rest of (5) isolates $(16.5 \%)$ were negative for DNase test.DNase production was detected by culturing the isolates on DNase agar, DNase is an extracellular enzyme that cleaved DNA into subunits composed of nucleotides (Oligonucleotides). The appearance of clear zone around bacterial growth was 
considered as the positive activity that indicated the presence of Deoxyribonuclease enzyme hydrolyses DNA (12).

Bacterial Genotyping: The phenol/chloroform extraction method was used for nucleic acid extraction and DNA was precipitated in $1 \mathrm{ml} 70$ per cent ethanol. The DNA precipitate was dissolved in $50 \mu$ of TE buffer $(10 \mathrm{mM}$ Tris chloride-1 mM EDTA(13). PCR cycles consisted of an initial denaturation step $\left(94^{\circ} \mathrm{C}\right.$ for $\left.5 \mathrm{~min}\right)$ followed by 30 amplification cycles (denaturation at $94^{\circ} \mathrm{C}$ for 60 seconds, annealing at $55^{\circ} \mathrm{C}$ for 60 seconds, and extension at $72^{\circ} \mathrm{C}$ for 60 seconds) with a final extensionat $72^{\circ} \mathrm{C}$ for $5 \mathrm{~min}$. The sequences of the primers(forward5'-TCCAATCATTGCACAAAATC3, reverse 5'-AATTCCCTCTATTTGGTGGT-3') . PCR product was resolved on a $2 \%$ agarose gel and stained with ethidium bromide and visualized under UV transillumination.

\section{Results:}

The presence of the msrAgene responsible for erythromycin resistance was confirmed by PCR analysis using primersmsrA gene.

This study have been revealed the Prevalence of msr A gene $(56 \%)$ in 14 out of 25 staphylococci isolates. Positive strains for msrA gene showed a band with $163 \mathrm{bp}$ in $2 \%$ agarose gel (Figure 1).

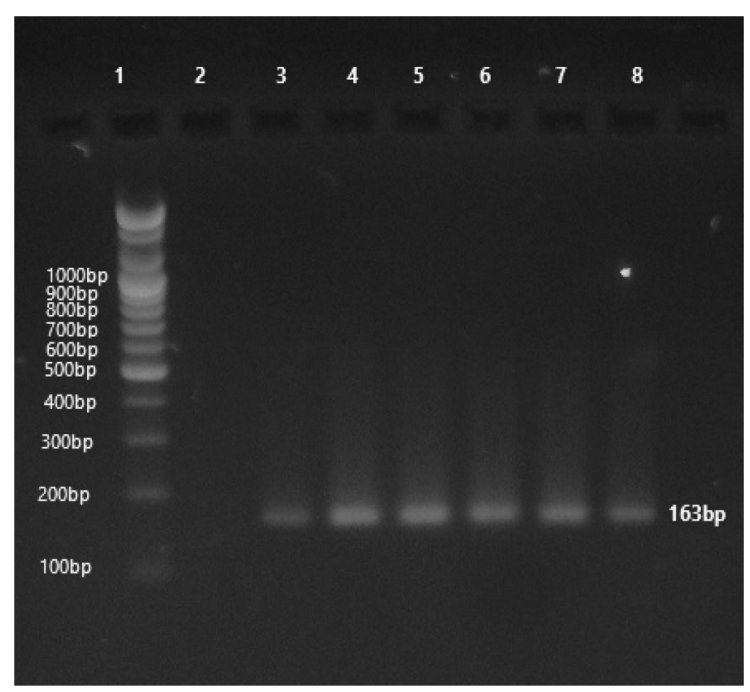

Figure1:Agarose gel electrophoresis (2\% agarose, for $60 \mathrm{~min} 5 \mathrm{~V} / \mathrm{cm}$,) for msrA gene (amplified size $163 \mathrm{bp}$ ) compared with (100 bp) DNA ladder, line 1 DNA Ladder; lines,3,4,5,6,7 and8 positive results of bands; lines 2 negative results.

\section{Discussion}

Staphylococcal strains resistant to macrolides and frequently harbour msrA gene, which encodes an ATP-dependent efflux pump (14).In this study, $56 \%$ of staphylococci isolates were msrA gene positive. It was found that msrA was detected among the resistant isolates, which further supported the evidence that efflux mechanism exist in the resistant Isolates. These findings are in contrast with the study by zmantar et al. (2013) conducted on staphylococci in Tunisia in which an incidence of(msrA) $36 \%$ positive(15). This finding was also shown byDing, Z.F et al( 2012). It was found that neither mefA nor msrA was detected amongthe resistant isolates(16). Franz-Josef et al ( 2000) also found that Macrolide resistance by efflux due to the msrA gene was only $13 \%$ in staphylococc isolates (17) . On the otherhand,our results are in agreement with Almer et al. (2002)(18) and Duran et al. (2012)(19).they found resistanceto erythromycin in staphylococci was 55.4 percent due to msrA gene that detected by PCR method. none of $44 \%$ our staphylococci isolates harboring with msrA gene. The resistance of these isolates presented due to the role of other resistance genes . in S. aureus isolates can resistant to macrolides by two mechanism, ATP-dependent efflux pump which encoded by mrs A gene as mentioned previously, and also effected by the role of membrane protein that coded by mef gene (20). other mechanism of resistance done by erm genes family that have about forty types of erm genes,only one type of erm genesexpression can lead to resistance against antibiotics (21).In conclusion,Utilization of the conventional PCR technology in the clinical laboratory enable physicians to prescribe suitable antibiotic therapy.The PCR is a useful and practical device for the routine diagnosis ofmacrolide resistance staphylococci use to the microbiology laboratory work flow.The detection of resistance genes in PCR was more reliable, accurate and specific than other method of detection.

\section{References}

1-Livermore DM. Antibiotic resistance in staphylococci. 1. Int $J$ Antimicrob Agents 2000; 16 : S3-S10.

2-Zapun A.,Contreras-Martel C., Vernet T., Penicillin-binding. 2. proteins and beta-lactam resistance. FEMS Microbiol Rev 2008; $32: 361-85$.

3-Schlegelova J., Babak V., Klimova E., Lukasova J., Navratilov

P., Sustackova A., Sediva I., Rysanek D.Prevalence of and resistance to anti-microbial drugs in selected microbial species isolated from bulk milksamples. J. of Veterinary Medicine Series B-Infectious Diseases and Veterinary Public Health 2000; 49:216-225.

4-Schlegelova J., Napravnikova E., Dendis M., Horvath RBenedikJ., BabakV., Klimova E., Navratilova P., SustackovaA. Beef carcass contamination in aslaughterhouse and prevalence of resistance to antimicrobialdrugs in isolates of selected microbial speciesMeat Science, 2004;66: 557-565.

5-Roberts, M. C., Sutcliffe, J., Courvalin, P., Jensen, L. B., Rood, J.Seppala, H. Nomenclature for macrolide and macrolidelincosamide streptogramin $B$ resistance determinants. AntimicrobAgents. Chemother. 43: 2823-2830.1999.;-

6-Peche're, J. C. Macrolide resistance mechanisms in Grampositivecocci. Int. J. Antimicrobial. Agents.2001.;18: 25-28.

7-Weisblum B. Inducible resistance to macrolides, lincosamides and streptogramin type B antibiotics - the resistance phenotype, 
its biological diversity, and structural elements that regulate expression - A Review.J.of Antimicrobial Chemotherapy.1985; 16:63-90.

8-Leclercq R. Mechanisms of resistance to macrolides and lincosamides Nature of the resistanceelements and their clinical implications. Oxford J.s. Clinical InfectiousDiseases. 2002; 34 : 482-492.

9-Luthje P., Schwarz S. Antimicrobial resistance of coagulasenegative staphylococci from bovine subclinicalmastitis with particular reference to macrolidelincosamideresistance phenotypes and genotypes.J.of Antimicrobial Chemotherapy.2002; 57: 966-969.

10-Bagcigil F.A., Moodley A., Baptiste K.E., Jensen V.F.,Guardabassi L.: $\quad$ Occurrence. species distribution,antimicrobial resistance and clonality of methicillin-and erythromycin-resistant staphylococci in thenasal cavity of domestic animals. Journal of Veterinary Microbiology.2007; 121: 307-315.

11- Sanli O., Özdemir M., Feyzioğlu B., Baykan M.:Research on Diagnostic Value of Real-Time PCR in comparison with culture method to detect agents for sepsis.Advances in Clinical and Medical Microbiology.2016;2:1-6

12-Gaasbeek, E.J., Wagenaar, J.A., Guilhabert, M.R., Wo"sten, M.M.S., van Putten, M.J.P., van der Graaf-van Bloois, M.L., Parker, C.T., van der Wal, F.J. A DNase encoded by integrated element CJIE1 inhibits natural transformation of Campylobacter jejuni. J. Bacteriol.2009; 191: 2296-2306. 13-Sambrook J, Fritschi EF and Maniatis T (1989) Molecular cloning: a laboratorymanual, Cold Spring Harbor Laboratory Press, New York.

14-Eady EA., Ross JI, Tipper JL., Walters CE., Cove JH., Noble WC.

Distribution of genes encoding erythromycin ribosomal methylases

and an erythromycin efflux pump in epidemiologically distinct groups

of staphylococci. J. Antimicrob. Chemother. 1993; 31:211-217 15-Zmantar,T., Bekir,K., Elgarsad,SI., Hadad,O.,Bakhrouf,A. Molecular investigation of antibiotic resistance genes inmethicillin resistant Staphylococcus aureus isolatedfrom nasal cavity in pediatric service. African J. of Microbiology Research.2013; 7: 4414-4421.

16-Ding, Z.F.,Zhang, H., Tang, W., Tong, C.Y., Li, R.T., Chen, L.X., Pu, L.J., Zhu, Z.B.2 and Cui, Y.D . Methylase GenesMediated Erythromycin Resistance in Staphylococcus aureus from Bovine Mastitis in China.2012. Israel J.of Veterinary Medicine.2012; 67:170-179.

17- Schmitza ,FJ., Sadurskia,R., Kraya,A., Boosa ,M., Geisela,R., Köhrera,K.,Verhoefb,J., Fluitb,AD. Prevalence of macrolide-resistance genes in Staphylococcus aureus and Enterococcus faecium isolates from 24 European university hospitals.Journal of Antimicrobial Chemotherapy 2000; 45:891-894.

18-Almer, LS., Shortridge, VD., Nilius, AM., Beyer, JM., Soni, NB., Bui, MH., Stone,GG., Flamm, RK. Antimicrobial susceptibility and molecularcharacterization of community- acquired methicillin-resistant Staphylococcus aureus. Diagn. Microbiol. Infect. Dis. 2002;43:225-232.

19-Duran N., Ozer B., Duran GG., Onlen Y., Demir C. Antibioticresistance genes and susceptibility patterns in staphylococci. Indian J. Med. Res. 2013;135:389-396. 20-Zmantar, T., Kouidhi, B., Miladi, H. ., Bakhrouf, A. Detection of macrolide and disinfectant resistance genes in clinical Staphylococcus aureus and coagulase-negative staphylococci. BMC Res Notes. 2011;4:453.

21-Stefanie, He., Gallert, C.Demonstration of staphylococci with

inducible macrolide lincosamide streptogramin B (MLSB) resistance

in sewage and river water and of the capacity of anhydroerythromycin to

induce MLSB. FEMS MicrobiolEcol. 2014;88:48- 59. 